GLOBAL DEVELOPMENT AND ENVIRONMENT INSTITUTE

Working PAPER No. 17-02

\title{
Missing from the Mainstream: \\ The Biophysical Basis of Production and the Public Economy
}

\author{
June Sekera
}

May 2017

Tufts University

Medford MA 02155, USA

http://ase.tufts.edu/gdae

(C) June Sekera 


\begin{abstract}
:
Just as mainstream economics neglects the biophysical basis of production and disregards energy as the most fundamental input, it likewise ignores the existence of the public economy. Both types of denialism threaten the ability of societies to develop energy solutions that can meet the needs of the polity. This article calls for a new theory of the public economy and it outlines elements of such a theory. Both a biophysical economics and a new public economics are needed to address the energy challenges confronting modern societies.
\end{abstract}




\title{
Missing from the Mainstream: The Biophysical Basis of Production and the Public Economy
}

\author{
June A. Sekera ${ }^{1}$
}

May 2017

One of the most important contributions of biophysical economics is its critique that mainstream economics disregards the biophysical basis of production (Hall et. al., 2001), and energy in particular (Hall and Klitgaard, 2012).

Likewise, mainstream economics ignores the existence of the public economy. The public economy is a vital system of production and delivery that produces scores of products: goods, services, benefits and innovations. Yet, standard economics lacks a theory of this non-market system.

To miss or minimize basic empirical verities - both the biophysical basis of production and the existence of the public non-market production economy - is not only astonishing denialism. ${ }^{2}$ Such obstinate myopia within economics may foreclose the development of solutions, such as alternative sources of high-EROI ${ }^{3}$ energy reliably produced and affordably supplied on a planetary scale.

\section{Denial of the public non-market system, and the consequences}

Public non-market production makes up a quarter to a half or more of all economic activity among advanced democratic nation-states. Yet the public economy's ability to function on behalf of the populace as a whole is seriously imperiled in many western democracies, and particularly jeopardized in the United States. The surging influence of mainstream economics has been a prime factor in the degradation of the public domain over the last several decades -- a phenomenon that James Galbraith (2008) has called "the collapse of the public governing capacity." Market advocates, exploiting neoclassical economic theory, have foisted market axioms and precepts onto government, intent on transforming public goods production in imitation of an idealized and idolized market model. The ravaging of government in the interests of ideology and private profit has proceeded largely unhampered because we have no adequate theory to explain the nature and dynamics of the non-market public economy, no intellectual infrastructure to explain how its purposes and processes differ crucially from those of the market, and no effective explanatory model that shows why such differences matter substantially for democratic governance and the well-being of the populace.

Government produces its outputs in a non-market environment. Its resource inputs are supplied collectively: from the authority of the people (their votes for elected

\footnotetext{
${ }^{1}$ Research Fellow, Global Development and Environment Institute; Tufts University

2 "Denialism: refusing to accept an empirically verifiable reality"

3 "Energy Return On Investment"
} 
representatives) and from their aggregate financing (taxes). The mission and the result of government's distributed decision-making, collective-financing system of production is that goods, services, benefits, and protection are supplied for the wellbeing of the society as a whole, and can be accessed regardless of personal wealth because they are provided free or below cost at the point of usage. Economic theory today lacks any cogent theory of this non-market system.

Public choice theory, to which many contemporary economists default for a "public economics," draws its lifeblood from market-centric ideology. The public choice school holds that the axioms and assertions of market-model economics apply to the public economy. Simply put, there are two fundamental problems with this school: 1) it fails to recognize that the public economy is non-market; and 2) many of the basic assumptions and assertions of market economics have been challenged and disproven by pluralist economists regarding their applicability to the market (e.g., see Fullbrook, Ed., 2007), nevermind the non-market.

A myopic market-centric view of the public economy prevails in textbooks, in university classrooms, in the documents and debates shaping public policy and in the current practice of public administration. As it stands now, students in university economics courses learn about the superiority of markets from a professoriate that transmits the reigning market-centric economics, that speaks regularly of government as little more than an impediment to "efficient markets," and that understands public goods as a problem of "market failure." In the United States, about $40 \%$ of college students take at least one economics course (Goodwin 2014); after graduation, more than half of economics majors go to work in government (Kalambokidis 2014).

My argument is that mainstream, market-centric economics has been broadly and dangerously transformative within government and public institutions. Market-centric economics is the smog that pervades the atmosphere of public policy and public administration, a smog that has at once caused and obscured many of the failures of what some say is a "broken government" (Schuck 2014, Howard 2014, T Smith 2014, Fahrenthold 2014, Luntz 2014). "Economic abstraction has been coupled with power to impose that abstraction throughout [the nation]. The result has been a political economy that generates the conditions for its own failure..."4

The consequences of the contrived and contorted imposition of market-model economics on the public domain range from the unfortunate to the disastrous. Agencies originally created to meet a public need are being warped into entities whose purpose is to generate revenue and deliver private profits at public expense. National parks are selling naming rights to corporations who will rebrand Yellowstone and Yosemite in their corporate images (Rein 2016, Olorunnipa 2016). The "policing-for-profit" model in criminal justice results in officers stopping motorists for minor infractions in order to make fee-and-fine quotas (U. S. Dept. of Justice 2015, anon. Harvard Law Review 2015, Zapotosky 2016). Public education - today being relabeled "government education" by

\footnotetext{
${ }^{4}$ Bowman et.al. 2014. The authors write principally about the UK, but their argument brilliantly captures the American reality too.
} 
those on the right - is being taken over by Wall Street, which has targeted "the education industry" as a new profit center through the spread of private "charter schools" funded by taxpayers, but shown in multiple studies to arrive at widely inferior results (Persson 2015, Losen et. al. 2016). Through "public-private-partnerships," multinational corporations build toll roads that go bankrupt, leaving taxpayers holding the bag. Private collection companies, contracted by government agencies, are being granted the sovereign power of the state to garnish wages of students, the poor, and other citizens in order to collect overdue debt AND fees and fines imposed by the companies themselves (Choudhury 2014, Edsall 2014, Shapiro 2014, Stillman 2014). Privatizers are very close to turning the venerable Veterans Health Administration into an ATM for the private healthcare industry, despite studies that have consistently shown that the VHA provides health care superior to private care systems (Farmer et al. 2016, MITRE 2015, Gordon 2015, Gordon 2016, Mundy 2016, Kime 2016). The result is a subversion and erosion of the capabilities of the public system of production, such that it can no longer deliver its intended results. A mission-model economic system, in which meeting public needs was the guiding purpose, is being distorted into a faux market-model system, in which revenue-raising becomes the goal.

While this transformation debilitates government overall, there is specific relevance to the growing energy challenges related to the biophysical constraints on economic activity and production. The historic role of government in leading and supporting basic scientific innovation is being hobbled. Regarding solutions to energy challenges in particular, we are confronted with what seem to be hopelessly complex problems that require: a long-term view; basic research financed by investments not tied to quarterly profits; breakthrough innovation; and development of society-wide solutions. These are the attributes not of the market, but rather, of the public non-market.

Indeed, the public non-market is the unrecognized innovator in our nation. Government has been the source - through its investments and leadership - of scores of breakthroughs that people often assume came from the private sector. Government's role in innovation has been documented by Mariana Mazzucato and Fred Block, among others, who have exploded the myth that all innovation is market-driven. A sampling includes:

\section{Debunking the Narrative of Silicon Valley's Innovation Myth}

\section{Forbes | Bruce Upbin}

"The real innovation engine in the global economy is not the entrepreneurial class blazing capitalist trails through the thicket of government red tape and taxation. No. The real engine of innovation is government." Economist Mariana Mazzucato's "case study for mythdebunking is the iPhone, that icon of American corporate innovation. Each of its core technologies-capacitive sensors, solid-state memory, the click wheel, GPS, internet, cellular communications, Siri, microchips, touchscreen - came from research efforts and funding support of the U.S. government and military. Did the public see an iPhone dividend? Not really." 


\section{The High Return on Investment for Publicly Funded Research}

Center for American Progress | Sean Pool and Jennifer Erickson

In order for the U.S. to maintain its role as an innovation-driven economy, "government must provide three key public-good inputs that allow innovation to blossom: investments in human capital, infrastructure, and research."

The authors cite and summarize the contributions of influential research funded by the U.S. Government through the Dept. of Energy Labs, The National Science Foundation, The Human Genome Project, The Defense Advanced Research Projects Agency and the Apollo Space Program.

\section{Markets, States, and the Green Transition}

\section{The American Prospect | Fred Block}

“... [U]nder-appreciated state involvement is true of many new technologies and sectors, but it emphatically describes the necessary transition to renewable energy. Private entrepreneurs contemplating investment in green energy face a chicken-and-egg problem. Technologies either do not yet exist, or they do not exist at a competitive price ... Unless government intervenes on the supply side - to promote the innovation that is too risky for private entrepreneurs - and on the demand side - to accelerate creation of mass markets for green sources of energy - private industry cannot get the job done."

\section{Innovation: let the good risk-takers get their reward}

\section{The Guardian |Mariana Mazzucato and William Lazonick}

Mazzucato and Lazonick write that, "the advanced economies of the west are in deep trouble. Growth is slow or non-existent, income distribution is highly unequal ... [and] the crucial question is how to reform policy so that the relationship between risk and reward is one that supports long-run growth rather than undermining it."

They point out that taxpayers are the real venture capitalists; taxpayers fund the riskiest investments in the "knowledge economy," but it is shareholders who receive recognition and profit for reputedly bearing the risk.

\section{The Seeds That Federal Money Can Plant}

\section{The New York Times | Steve Lohr}

"Government support plays a vital role in incubating new ideas that are harvested by the private sector, sometimes many years later, creating companies and jobs."

The author cites a report from the National Research Council that finds nearly $\$ 500$ billion a year of revenue at "30 well-known corporations ... [can] be traced back to the seed research backed by government agencies." 
Imagine spending a day without the Internet and GPS

Continuing Innovation in Information Technology $\mid$ National Research Council

The internet and GPS (a U.S.-owned utility) are among many innovations that have been funded by the U.S. Government. The authors of Continuing Innovation in Information Technology write, "fundamental research in IT, conducted in industry and universities, has led to the introduction of entirely new producer categories that ultimately became billion-dollar industries."

Underscoring the impact of government's outsized role in creating the dominant technologies of the 21st century, the authors of this report ask readers to imagine a day without information technology. "This would be a day without the Internet and all that it enables ... A day without digital media ... A day during which aircraft could not fly, travelers had to navigate without benefit of the Global Positioning System (GPS), weather forecasters had no models, [and] banks and merchants could not transfer funds electronically..."

The economic system that produced these innovations - the public non-market economy - of which government is the agent, remains unrecognized in contemporary mainstream economics, which is blind to it as a valid, viable, essential production system.

\section{Elements of the public nonmarket}

In the public non-market, the most basic constructs of mainstream economics do not apply. There is no "exchange" between "buyers," and "sellers." There is no marketmodel competition, only "pseudo-privatization" (Siltala 2013). The driver is not demand but identified societal need. Satisfying "customers" does not produce revenue. The monopsonist is often rendered powerless to set prices. Government expenditure actually results in "crowding-in," boosting rather than curtailing growth. In a non-market, outcome goals are devilishly difficult to define - unlike the simple market goal of maximizing profit. Results are often obscured because of factors unique to non-markets, where invisibility of outputs and absence of harmful conditions are hallmarks of success.

The public non-market is the economy in which the production of goods, services and other products is capitalized collectively (through taxes), and is empowered through collective choice (voting), and in which products are provided free or below cost at the point of receipt or usage. In The Public Economy in Crisis: A Call for a New Public Economics, (Sekera 2016) I outline the elements of a new theory of the public nonmarket economy. In summary, these include:

- The systemic purpose is meeting unmet societal needs; not maximizing profits.

- The public nonmarket is need-driven, not demand-driven. Collective choice replaces demand.

- The two fundamental systemic drivers are collective choice and collective payment. 
- Flow relationships and dynamics are intrinsically different in the two economic systems. The market is an exchange; the public nonmarket is a three-node flow. See Figure 1.

\section{Figure 1}

MARKET VS. PUBLIC NON-MARKET DYNAMICS

MARKET

\section{EXCHANGE}
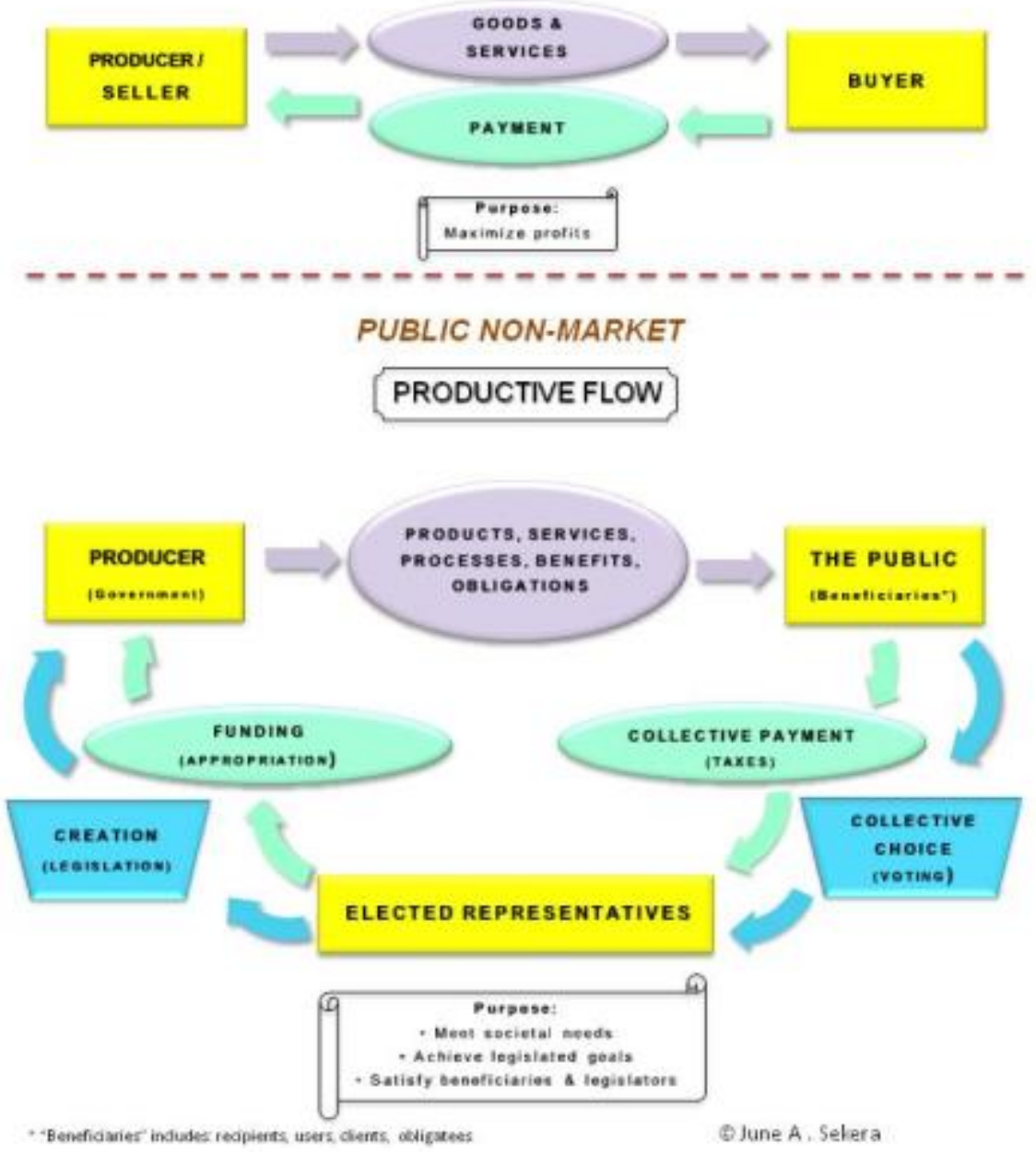

And there are other intrinsic differences:

- Products. The market produces goods and services; the public non-market produces goods, services, benefits and obligations. "Obligations," such as the obligation of drivers to obey speed limits and of factories to obey pollution regulations, are a unique product of the public nonmarket (Moore 2014). In a democratic nation-state, such power is conferred by the polity through voting. 
- Invisibility. In the public non-market invisibility is a hallmark of effectiveness: needs met; problems solved; harms that do not happen because of effective protection.

- Results measurement. Businesses' success is measured by profitability (since profits are required for survival), which is quite simple in comparison to the nonmarket. In the public non-market defining measurable outcomes in a way that obtains valid, useful measurements, and that avoids unintended consequences is extraordinarily complex and confounding difficult. Exhibit $\mathrm{A}$ is public education: measuring the effectiveness of education through student testing alone. There are dozens more examples of the dismaying, and often disturbing, techniques that have been applied all across government and backfired, underscoring the difficulty of measuring nonmarket outcomes in a meaningful, useful and valid way.

Each of the characteristics listed above is discussed in detail in my book, The Public Economy in Crisis: A Call for a New Public Economics.

\section{What happened? A transformation within economics and an absence of theory today.}

More than a century ago, the effective operation of the public economy was a significant, active concern of economists. With the insurgence of market-centrism and rational choice economics, however, government was devalued, its role circumscribed and seen from a perspective of "market failure." As Backhouse (2005) has shown, the transformation in economic thinking in the latter half of the $20^{\text {th }}$ century led to a "radical shift" in worldview regarding the role of the state. The very idea of a valid, valuable public non-market has almost disappeared from sight.

In $18^{\text {th }}$ and $19^{\text {th }}$ century Germany, Kameralwissenschaft ("Cameralism") represented a form of public economics. Backhouse (2002, p. 166), describes this school as the era's "science of economic administration," which had three components: public finance, economics, and public policy. The "Historical School" of economics emerged in later $19^{\text {th }}$ century Germany and viewed government positively as a system for promoting social well-being (Bogart 1939; Shionoya 2005). It stopped short, however, of explaining the operational or production aspects of the system. During the late $19^{\text {th }}$ and early $20^{\text {th }}$ centuries, economists wrestled with the question of how the "public economy" operates. A "voluntary exchange" theory of the public economy was advanced by Emil Sax, DeViti De Marco, Knut Wicksell and Erik Lindahl (Sekera 2016). During the 1940s-50s, Richard Musgrave argued against the voluntary exchange concept and pursued a line of thinking that led to the construction of a concept of "public goods" that was eventually adopted, mathematicized and popularized by Samuelson (Desmarais-Tremblay 2013). Samuelson's widely-disseminated 1950s formulation of public goods as stemming from market failure (following Musgrave) soon led to their devaluation, and a wholesale devaluation of government, by market centrists and libertarians, eventually by all tributaries of mainstream economics. What had begun as a serious effort to understand the important role of public sector production ended in its willful neglect. 
In an important paper, Roger Backhouse (2005) describes the "profound changes in economic theory" that took place between 1970 and 2000. With the triumph of rational-choice economics came "a radical shift of worldview" and a "remarkable and dramatic change in attitudes toward the role of the state in economic activity." The rise of "free market" economics and the "ideology of rational choice" created a "climate of opinion" that seriously biased economics against government and led to a view of the state as an agent whose actions lead to perverse outcomes. As Backhouse shows, however, "the shift toward market solutions did not occur spontaneously: it was actively promoted by groups of economists committed to opposing socialism [and] making the case for free enterprise."

In his landmark book, A Perilous Progress: Economists and Public Purpose in Twentieth-Century America (2001), Michael Bernstein explores the evolution of economics from an academic field marginal to public policy into a powerhouse that influenced and oriented government decision-making. Economists in the late $19^{\text {th }}$ and early $20^{\text {th }}$ centuries ardently sought to cultivate influence with elected and appointed officials to shape public policy and contribute to "purposeful management" and "statecraft." These were among the driving ambitions of the economists who led the American Economics Association after its founding in 1885. Seeking respect for economics as a new "scientific" field (no longer framed philosophically as "political economy"), "scholars sought a privileged and powerful access to public policy debate, formulation and implementation." Once the influential Cambridge University economist Arthur C. Pigou asserted in 1922 that it was not the business of economists to tell businessmen how to run their companies, it became all the more critical that economists claim for their discipline a legitimate role in statecraft. And they got their big chance in war. Tracing the many roads by which economists entered the public arena, Bernstein finds that the profession came fully into its own through its impact on national decisionmaking during World War II. Ironically, "Not individualism but rather statism provided the special circumstances" for American economists to obtain prestige and power (p. 89). "In point of fact, it was statism and centralized economic policy practice that had brought economists and their discipline to the prominence and influence they [came to] enjoy ( $\mathrm{p}$. 194)."

Yet even when applying their theories and practices to the non-market environment of government, mainstream economists have relied insistently on the market model. Because mainstream economists in the U.S. and elsewhere have been so marketfocused for so long, production outside the market has been erased from the equations of economics. So now, government action is regarded as an "intervention" that "distorts" smooth operation of an otherwise beneficent market. Government is considered to have an economic role only (or primarily) in cases of so called "market failure." Consequently, there is no viable and explanatory concept of an actual, let alone a legitimate, public nonmarket economy. So pervasive is the creed that government only "intervenes" in what is thought to be the valid, market economy that even literature from the Congressional Research Service (Labonte 2010) relegates government to an outsider role. 
The term "non-market" and its meaning remain elusive. For example, Karl Polanyi wrote extensively about the differences between markets and non-markets but did not deal with the dynamics and forces of production in the non-market public economy (Krippner 2001, Mayhew 2016, Zaman 2016). Polanyi argued that the market was embedded within, and enabled by, the public sector, but did not concern himself with the operations - forces, dynamics, drivers - of the public non-market system itself. Neither do such widely-cited economists of the public sector as Robert Dahl and Charles Lindblom, Charles Wolf or Kenneth Arrow (Sekera 2016). Joseph Stiglitz produced an entire textbook on "the economics of the public sector" (the latest edition in 2000) without recognizing the distinctive characteristics of a public non-market.

As I noted earlier, the "public choice" school has become the framework to which economists default for an explanation of the public economy. Backhouse (2005) outlines the development of the public choice school, which stems from a cluster of works published in the 1950s and 1960s by James Buchanan, Gordon Tullock, Mancur Olson, and Anthony Downs. It became a school, and a movement, when James Buchanan and Warren Nutter found a home for their efforts at George Mason University in Virginia. In the mid-1980s George Mason opened the Center for the Study of Market Processes, with its largest supporter being the Koch Family Foundations. Stretton and Orchard (1994) have demonstrated the anti-government, anti-democratic stance of public choice theorists in their extensive treatment of the school in Public Goods, Public Enterprise, Public Choice; Theoretical Foundations of the Contemporary Attack on Government. After critiquing the theory in economics terms, they suggest that public choice "reasoning seems to arise from the theorists' reluctance to 'come out' and identify themselves as open enemies of democracy or at least of universal suffrage...Governments are viewed as exploiters of the citizenry, rather than the means through which the citizenry secures for itself goods and services that can best be provided jointly or collectively."

A theory of the public nonmarket remains woefully lacking. The absence is not just an academic gap; it leaves a vacuum that undermines the public provisioning required to meet societal needs and to develop solutions to pressing common problems, including the depletion of high-EROI energy sources.

\section{Dealing with energy challenges: the connection between public economics and biophysical economics}

Orthodox economics "posits that marketplace dynamics will determine the energy transition from fossil fuels to something else through the price mechanism" and "assumes that innovation will appear as needed" (Cobb 2010). There is little evidence to support either the postulate or the assumption.

A new economics is called for. In fact, two: biophysical economics and a new public economics. Readers familiar with environmental economic dynamics no doubt understand the need for a biophysical economics that recognizes and takes account of the inherent limits of the biophysical world. Such an economics, while essential, is not 
sufficient. Solutions to the energy challenges we face will necessitate both a new, biophysical understanding of production and a new understanding and conceptual model of the public economic system. Neither is entirely sufficient without the other.

The energy transition will require breakthrough innovation. Both theory and the history of recent decades demonstrate that solutions to technologically complex, common-need problems require scientific breakthroughs that come through distributed decision-making and collective action ${ }^{5}$ and that will not come from market forces alone, if at all. Such solutions require long time-horizon investment: investments with no immediate payoff in terms of saleable products, no visible ROI (return on investment), no profit-making in the near-term. Such investment can be generated only in a non-market environment, in which payment is collective and financial profit is not the point.

Moreover, in the modern market, businesses, backed by profit-driven investors, intentionally produce products with a surfeit of waste baked in, a characteristic inimical to an energy transition that seeks to minimize energy waste. The production of extraordinary waste is inherent to the modern, market business model (MacKinnon 2016; Allison Arieff; 2016). Today's business model, particularly that of technology corporations, has created a "throw-away" culture with a value system that fosters the discard of millions of electronic devices or components (Urry 2016) and adheres to a design formula that intentionally makes repair impossible or difficult (Matchar 2016). While laying claim to "efficiency" as an alleged attribute (often achieved merely through labor cost reductions), the American business model is geared to "repetitive consumption" and "planned obsolescence" (MacKinnon 2016). The second law of thermodynamics tells us that waste is an intrinsic feature of the use of energy in production. But there is a qualitative, and controllable, difference between the level of necessary "waste" generated by energy conversion and that gratuitous waste inherent in the modern American business model, a wastefulness that goes unaddressed by market economics. Ecological economist Herman Daly (1998a, 1998b, 2003), having shown how "The concepts of throughput, of entropy... are foreign" to "mainstream neoclassical economists," argues for an economic policy of "frugality first." He defines frugality as "non-wasteful sufficiency". Such frugality is not a characteristic of modern market production.

The market is not constituted to produce solutions to extraordinarily complex, technological common-need problems. This is so even if market actors start to perceive the biophysical basis for production. The inherent, driving forces and dynamics of the modern market - short time horizons, growth as a requisite, gratuitous waste baked-in, profits as life-blood - render it incapable of producing solutions that demand long-view investment without profits. The challenges we face may be unprecedented. In a paper on "EROI of Different Fuels and the Implications for Society," Hall, Lambert \& Balogh (2014) conclude:

\footnotetext{
${ }^{5}$ Collective action in a democratic society is exercised through distributed decision-making (voting) and is financed through collective payment (taxes). Note that collective action and collective payment are not synonymous with state-ownership of enterprises. The matter of state-owned enterprises that respond to market forces is not material to the issues I am describing here.
} 
The decline in EROI among major fossil fuels suggests that in the race between technological advances and depletion, depletion is winning. .... Thus society seems to be caught in a dilemma unlike anything experienced in the last few centuries. During that time most problems (such as needs for more agricultural output, worker pay, transport, pensions, schools and social services) were solved by throwing more technology investments and energy at the problem... We believe that the future is likely to be very different, for while there remains considerable energy in the ground it is unlikely to be exploitable cheaply, or eventually at all, because of its decreasing EROI.

Many will advocate "market-based solutions" or "public-private-partnerships" as the route to take, based on a misplaced faith or ideological belief in the market. Kate Aronoff, (2015) a former organizer with the fossil fuel divestment movement, sees evidence that the positioning of corporate leaders will enable them to make the case that "the free market is better suited than the state to take on the climate crisis." Indeed, investors are hovering, anxious to profit from EROI decline. Wall Street and private equity investors see new opportunities for profit, often at the public's expense. Libertarian venture capitalist Peter Theil (2015) (PayPal cofounder) wrote about the opportunity he sees as an investor: "We already know that today's energy sources cannot sustain a future we want to live in... The need for energy alternatives was already clear to investors a decade ago..." Henry Paulson (Paulson 2016), former Chairman and Chief Executive Officer of Goldman Sachs, former Secretary of the Treasury and now head of the Paulson Institute, says "Saving our planet from the worst effects of climate change won't be cheap...governments must create conditions that encourage private investment in clean technologies and sustainable development... incentives and subsidies for clean energy investments" are needed. [Emphasis added]. For Theil, atomic energy is the solution. Americans need not suffer a decline in living standards or businesses sacrifice growth, he implies. But government regulation and "liberals" with a "fear of technology" stand in the way of "venture capitalists like me ready to put money behind nuclear power." However, muting regulators or mooting regulations so that investor money can flow may not be the path to the optimal energy solution for the polity, or perhaps for the planet. Nevertheless, if the history of recent decades is a guide, corporations will seek, and obtain, public subsidies to underwrite their technology development process.

One way or another there will be government investment. The only question is who will control the use of those investments? Market actors whose purpose is private profit-making? Or the collective choice of the polity, who, long term, will be the beneficiary or the victim of those investments? Is government up to the work that needs to be done? Given the scant attention paid to biophysical constraints among economists who advise government and even much of the scientific community, given the proclivity on all sides to look to market-like solutions, and given a hollowed-out, outsourced and degraded government, that question is scarcely rhetorical. 
A paper by Day et al. (forthcoming) on "The Energy Pillars of Society" observes that new "policy" is needed, and expresses concern that the policy makers won't get it right.

[The] issue is that societal net energy yield is falling. Adopting growthbased economic policy without consideration of net energy yield is likely to leave society vulnerable to a future without sufficient energy to provide for basic needs. More careful analysis of resources and economy, incorporating net energy, is necessary to inform policy and management during the coming energy transition.

Many crucial aspects of the proposed transition, net energy and resource constraints in particular, have been largely overlooked by policymakers and much of the scientific community. Our central thesis here is that proposed climate-related energy policies will be impacted and often restricted by biophysical constraints, especially net energy and total production. Serious economic and societal displacements will occur if the existing energy system is disrupted.

Governments and major policy agencies must recognize how biophysical constraints will impact plans for the future and develop research programs that are aimed at investigating the tradeoffs of society's energy investments within the context of net energy and resource constraints. Obviously further energy research in all sectors is warranted. Policy must also prioritize fossil fuel conservation and system wide efficiency. We cannot stress enough the importance that all energy research and policy is guided by a systems based understanding of the biophysical constraints (especially, net energy) that govern the natural world. [Emphasis in original].

Yes, policy makers need to understand the biophysical imperative: that societal net energy yield is falling. Hence the need for a biophysical economics, and for policymakers to comprehend its central messages. But the other major issue is that policy-makers - both the leaders and the public servants who write policy "options papers" for them -- have been taught to embrace "market solutions" for every sort of societal need, from education, to infrastructure, to water supply and national security. "Market solutions" is the tide that has swept in across the public sector, "public-privatepartnerships" the wave that has been flooding all parts of government for more than 30 years, with ever-more destructive force. We need a new public economics that comprehends and embraces the public purposes of the public domain, and which supports long-view policies that both solve the problem and serve the public

Only an economic system that can spawn breakthrough innovations with no profit in sight, and only one in which gratuitous waste is not intentionally baked-in (for the sake of future profits) can come up with the solutions. In current nation-states, that system is the public nonmarket economy, of which government is the agent. But the public 
nonmarket is being dismantled, hollowed-out, outsourced, privatized. If this degradation continues, if the public economy continues to be contorted into a faux-market system, if collective payment as the financing method continues to be choked off or diverted to private profits, if government is increasingly forced to make revenue-generation a goal, and if large swaths of the public nonmarket continue to be captured by profit-maximizing corporations, then the public nonmarket will have ceased to become the source of the solution. Indeed, it will have ceased to exist. 


\section{REFERENCES}

anon. (2015) "Policing and Profit" Harvard Law Review, Vol 128, No. 6, April 10, 2015. http://harvardlawreview.org/2015/04/policing-and-profit/

Arieff, Allison (2016) "Solving All the Wrong Problems" New York Times, July 10, 2016.

Aronoff, Kate (2015) “The Death of Climate Denialism”, In These Times, June 15, 2015 http://inthesetimes.com/article/18040/the-death-of-climate-denialism

Backhouse, Roger E (2002) The ordinary business of life: a history of economics from the ancient world to the twenty-first century. Princeton University, Princeton and Oxford

Backhouse, Roger E (2005) The rise of free market economics: economists and the role of the State since 1970. Hist. Polit. Econ. 37(Suppl 1): 355-392. doi:10.1215/00182702-37-Suppl_1-355

Bernstein, Michael A (2001) A perilous progress: economists and public purpose in twentieth-century America. Princeton University, Princeton

Bogart, Ernst L (1939) Government expansion in the economic sphere. Annals Amer. Acad. Polit. Soc. Sci. 206: 1-5

Bowman, Andrew, Julie Froud, Sukhdev Johal, John Law, Adam Leaver, Mick Moran, and Karel Williams (2014) The end of the experiment? From competition to the foundational economy. Manchester University, Manchester; Palgrave Macmillan, New York

Choudhury, Nusrat (2014, February 6) Court-sanctioned extortion by private probation companies: modern debtors' prisons. ACLU blog, concerning the Human Rights Watch report,

Profiting from probation. https://www.aclu.org/blog/court-sanctioned-extortion-privateprobation-companies-modern-debtors-prisons

Cobb, Kurt (2010) "Biophysical economics: Putting energy at the center"; Scitizen, Jan. $21,2010$.

Daly, Herman E. (1998a) “Consumption: Value added, physical transformation, and welfare.” In David A. Crocker and Toby Linden, eds., Ethics of Consumption: The Good Life, Justice, and Global Stewardship. Lanham: Rowman and Littlefield, pages 19-27.

Daly, Herman E. (1998b) "Reply to Mark Sagoff's 'Carrying Capacity and Ecological Economics.” In David A. Crocker and Toby Linden, eds., Ethics of Consumption: The Good Life, Justice, and Global Stewardship. Lanham: Rowman and Littlefield, pages 53-62.

Daly, Herman E. (2003) "The Illth of Nations and the Fecklessness of Policy: An Ecological Economist's Perspective" Post-Autistic Economics Review, No. 22, Nov. 24, 2003, article 1.

Day, John W., Christopher F D'Elia, Charles Hall, Adrian R.H. Wiegman, Jeffrey S Rutherford, Robert L Lane, David E Dismukes, "The Energy Pillars of Society and the Transition to Renewables," forthcoming.

Desmarais-Tremblay, Maxime (2013, May) On the definition of public goods: assessing Richard A. Musgrave's contribution. Paper presented at 17th Annual Conf Europ Soc Hist Econ Thought, Kingston University, London. Also available at 
Documents de travail du Centre d'Economie de la Sorbonne.

https://halshs.archives-ouvertes.fr/halshs-00951577/document

Edsall, Thomas B (2014, August 26) The expanding world of poverty capitalism. New York Times, Opinion Pages

Fahrenthold, David A (2014, May 30) Breaking points: where government falls apart; how the VA developed Its culture of coverups. Washington Post

Farmer, Carrie M., Susan D. Hosek and David M. Adamson. Balancing Demand and Supply for Veterans' Health Care: A Summary of Three RAND Assessments Conducted Under the Veterans Choice Act. Santa Monica, CA: RAND Corporation (2016). http://www.rand.org/pubs/research_reports/RR1165z4.html

Fullbrook, Edward ed.(2007) Real world economics; a post-autistic economics reader. Anthem Press, London

Galbraith, James K (2008) The predator state: how conservatives have abandoned the free market and why liberals should too. Free Press, New York

Goodwin, Neva R (2014) The human element in the new economics: a 60-year refresh for economic thinking and teaching. Real World Econ. Rev. Issue 68: 98-118. http://www.paecon.net/PAEReview/

Gordon, Suzanne (2015) "Report: VA Outperforms Private Sector on Key Measures" The American Prospect, Nov. 20, 2015 http://prospect.org/article/report-vaoutperforms-private-sector-key-measures

Gordon, Suzanne (2016) Congressional Commission Moves Toward Privatization of VA, American Prospect, Feb. 9, 2016. http://prospect.org/blog/tapped/congressionalcommission-moves-toward-privatization-va

Gowdy, J., Hall, C., Klitgaard, K., and L. Krall. 2010. The End of Faith Based Economics. The Corporate Examiner. 37: No. 4-5: 5-11.

Hall, C.A.S., and K. Klitgaard. 2012. Energy and the Wealth of Nations: Understanding the Biophysical Economy. Springer, NY.

Hall, Charles, D. Lindenberger, Reiner Kummel, T. Kroeger, and W. Eichhorn. 2001. The need to reintegrate the natural sciences with economics. BioScience 51 (6): 663-673.

Hall, Charles A.S., Jessica G.Lambert, Stephen B. Balogh (2014) EROI of different fuels and the implications for society. Energy Policy. 64,: 141-152.

Howard, Philip (2014) The rule of nobody: saving America from dead laws and broken government. W W Norton.

Kalambokidis, Laura (2014) Creating public value with tax and spending policies: the view from public economics. Public Admin. Rev. 74(4): 519-526. doi: 10.1111/puar.12162

Kime, Patricia (2016) "Panel weighs closing all VA health care — vets' groups raise conflict of interest" Military Times, April 1, 2016. http://www.militarytimes.com/story/veterans/2016/04/01/panel-weighs-closingall-va-health-care-vets-groups-raise-conflict-interest/82522000/

Krippner, Greta R. (2001) "The elusive market: Embeddedness and the paradigm of economic sociology. Theory and Society 30: 775^810, 2001.

Labonte, Marc (2010, June 14) Size and role of government: economic issues. Congressional Research Service Report, 7-5700 
Losen, Daniel J., Michael A. Keith II, Cheri L. Hodson, Tia E. Martinez (2016) "Charter Schools, Civil Rights and School Discipline: A Comprehensive Review," Civil Rights Project UCLA, March 16, 2016. https://civilrightsproject.ucla.edu/resources/projects/center-for-civil-rightsremedies/school-to-pris on-folder/federal-reports/charter-schools-civil-rights-andschool-discipline-a-comprehensive-review

Luntz, Frank (2014, November 5) The midterms were not a Republican revolution. New York Times, pA31 New York print edition. http://www.nytimes.com/2014/11/06/opinion/the-midterms-were-not-arepublican-revolution.html

MacKinnon, J. B. (2016) The Great L.E.D. Quandary. New Yorker, July 14, 2016 http://www.newyorker.com/business/currency/the-l-e-d-quandary-why-theres-nosuch-thing-as-built-to-last

Matchar, Emily (2016, July 13) The fight for the 'Right to Repair'. smithsonian.com http://www.smithsonianmag.com/innovation/fight-right-repair-180959764/?no-ist

Mayhew, Anne. (2016) 'A Commentary on Asad Zaman's paper: "The Methodology of Polanyi's Great Transformation" Economic Thought, 5.1, pp. 64-69. http://www.worldeconomicsassociation.org/files/journals/economicthought/WEA -ET-5-1-Mayhew.pdf

MITRE (2015), Independent Assessment of the Health Care Delivery Systems and Management Processes of the Department of Veterans Affairs, Vol. 1, The MITRE Corporation, Sept. 1, 2015

Moore, Mark H (2014) Public Value accounting: establishing the philosophical basis. Public Admin. Rev. 74(4): 465-477. doi: 10.1111/puar.12198

Mundy, Alicia (2016) “The VA Isn’t Broken, Yet” Washington Monthly, March/April/May 2016.

http://www.washingtonmonthly.com/magazine/marchaprilmay_2016/features/the _va_isnt_broken_yet059847.php?page=all

Olorunnipa, Toluse (2016) "Hurting for Cash, U.S. National Parks Turn to Companies", Bloomberg News, June 17, 2016, http://www.bloomberg.com/politics/articles/2016-06-17/hurting-for-cash-u-snational-park-service-turns-to-companies

Paulson, Henry (2016, Sept. 20 "How to raise trillions for green investments", New York Times http://www.nytimes.com/2016/09/20/opinion/how-to-raise-trillions-forgreen-investments.html? $\mathrm{r}=0$

Persson, Jonas (2015) "CMD Publishes List of Closed Charter Schools", PRWatch, Sept. 22, 2015) http://www.prwatch.org/news/2015/09/12936/cmd-publishes-full-list2500-closed-charter-schools

Rein, Lisa (2016) "Yosemite, Sponsored by Starbucks? National Parks to start selling some naming rights.”, Washington Post, May 9, 2016 https://www.washingtonpost.com/news/powerpost/wp/2016/05/09/yosemitenational-park-brought-to-you-by-starbucks/

Schuck, Peter H (2014) Why government fails so often, and how it can do better. Princeton University, Princeton

Sekera, June (2016) The Public Economy in Crisis; A Call for a New Public Economics, Springer Briefs in Economics. 
Shapiro, Joseph (2014, May 19) As court fees rise, the poor are paying the price. National Public Radio, News Investigations, with update on May 23.

http://www.npr.org/2014/05/19/312158516/increasing-court-fees-punish-the-poor

Shionoya, Yuichi (2005) The soul of the German Historical School; methodological essays on Schmoller, Weber, and Schumpeter. Springer, Boston

Siltala, Juha (2013) New public management: the evidence-based worst practice? Admin. 45(4): 468-493. doi:10.1177/0095399713483385

Smith, Thomas A (2014) [Review of Why government fails so often, by Peter Schuck and Simeon E. Baldwin.] Yale Alumni Mag. 77(6): 58

https://yalealumnimagazine.com/articles/3936/reviews

Stillman, Sarah (2014, June 23) Get out of jail inc. New Yorker. http://www.newyorker.com/magazine/2014/06/23/get-out-of-jail-inc

Stretton, Hugh, and Lionel Orchard (1994) Public goods, public enterprise, public choice - the theoretical foundations for the contemporary attack on government. St. Martin's, New York

Thiel, Peter (2015) “The New Atomic Age We Need”, New York Times, Nov. 27, 2015.

Urry, Amelia (2016, Oct. 11) Apple's recycling robot wants your old iPhone. Don't give it to him. Grist.org. http://grist.org/business-technology/apples-recycling-robotwants-your-old-iphone-dont-give-it-to-him/

U.S. Department of Justice (March 2015) Investigation of the Ferguson Police Department.

Zaman, Asad. (2016) 'The Methodology of Polanyi's Great Transformation.' Economic Thought, 5.1 . http://www.worldeconomicsassociation.org/files/journals/economicthought/WEA -ET-5-1-Zaman.pdf

Zapotosky, Matt (2016) "Justice Department warns local courts about unlawful fines and fees", Washington Post, March 14, 2016 